\title{
Optimalisasi Waktu Pengomposan dan Kualitas Pupuk Kandang dari Kotoran Kambing dan Debu Sabut Kelapa dengan Bioaktivator PROMI dan Orgadec
}

\author{
Time Optimization of the Composting and Quality of Organic Fertilizer Based on Goat \\ Manure and Coconut Coir Dust using PROMI and Orgadec Bio-Activator
}

\author{
Linda Trivana, Adhitya Yudha Pradhana \\ Balai Penelitian Tanaman Palma \\ Jalan Raya Mapanget, Kotak Pos 1004 Manado 95001 \\ Email: lindatrivana@gmail.com
}

\begin{abstract}
Animal manures can be used as organic fertilizer because the high nutrient content such as nitrogen $(\mathrm{N})$, phosphorus $(\mathrm{P})$, and potassium $(\mathrm{K})$. The nutrients are needed by plants and soil for fertility. One of the animal manures that can be used for organic fertilizer is goat manure. Goat manure is used as organic fertilizer it contains relatively more balanced nutrients than other natural fertilizer. In addition, the goat manure is mixed with the goat urine that also contains high nutrients. Coconut coir dust contains high potassium so that the addition of coconut coir dust in organic fertilizer will increase the potassium content $(\mathrm{K})$ in organic fertilizer. The purpose of this research was to find out the influence of effective Orgadec and PROMI bioactivators on the optimal time of composting and the quality of the organic fertilizer. The organic fertilizer was analyzed to determine the content of $\mathrm{N}, \mathrm{P}, \mathrm{K}$, organic- $\mathrm{C}, \mathrm{C} / \mathrm{N}$ ratio, water content, and $\mathrm{pH}$. The result of analysis is compared with SNI 19-7030-2004. Organic fertilizer analysis was conducted on day $0,10,20,30,40$, and 50 . The result of the organic fertilizer analysis with Orgadec bio-activator more effective and faster on the decomposition organic matter in the compost compared PROMI ( $<20$ days). The quality of organic fertilizer with Orgadec bioactivator on day 10 and 20, while organic fertilizer with PROMI on day 20,30, 40, and 50 days was in accordance with the quality stated in SNI 19-7030-2004 (C/N ratio, levels of N, P, K, water, and organic-C).
\end{abstract}

Keywords : goat manure, coconut coir dust, Orgadec, PROMI

\begin{abstract}
Abstrak
Kotoran ternak dapat dimanfaatkan sebagai pupuk kandang karena kandungan unsur hara seperti nitrogen $(\mathrm{N})$, fosfor (P), dan kalium (K) yang dibutuhkan oleh tanaman dan kesuburan tanah. Salah satu kotoran ternak yang dapat digunakan untuk pupuk kandang adalah kotoran kambing. Kotoran kambing digunakan sebagai pupuk kandang didasari oleh alasan bahwa kotoran kambing memiliki kandungan unsur hara relatif lebih seimbang dibanding pupuk alam lainnya dan kotoran kambing bercampur dengan air seninya (urine) yang juga mengandung unsur hara. Penambahan debu sabut kelapa ke dalam pupuk kandang karena kandungan kalium yang tinggi pada debu sabut dapat meningkatkan kandungan unsur hara K pada pupuk kandang. Penelitian ini bertujuan untuk mengetahui pengaruh pemberian bioaktivator yang berbeda (PROMI dan Orgadec) terhadap waktu optimal pengomposan dan kualitas pupuk kandang sesuai dengan SNI 19-7030-2004. Pupuk kandang yang diperoleh dianalisis kadar N, P, K, C-organik, rasio C/N, dan kadar airnya. Hasil analisis dibandingkan dengan SNI 19-7030-2004. Analisis pupuk kandang dilakukan pada hari ke $0,10,20,30,40$, dan 50. Hasil analisis pupuk kandang dengan bioaktivator Orgadec lebih efektif dan memerlukan waktu yang lebih cepat untuk mendekomposisi bahan organik dalam kompos daripada dengan bioaktivator PROMI, yaitu $<20$ hari. Kualitas pupuk kandang yang memenuhi SNI 19-7030-2004 (rasio $\mathrm{C} / \mathrm{N}$, kadar N, P, K, air, dan C-organik), yaitu pupuk kandang dengan bioaktivator Orgadec pada pengomposan selama 10 dan 20 hari, sedangkan pupuk kandang dengan bioaktivator PROMI pada pengomposan selama 20, 30, 40, dan 50 hari.
\end{abstract}

Kata Kunci: kotoran kambing, debu sabut kelapa, Orgadec, PROMI 


\section{Pendahuluan}

Limbah peternakan seperti feces, urine, dan sisa pakan yang dibiarkan tanpa penanganan lebih lanjut dapat menyebabkan pencemaran lingkungan dan gangguan kesehatan pada masyarakat di sekitar peternakan. Pengolahan kotoran ternak perlu dilakukan untuk mengurangi pencemaran lingkungan. Pengolahan kotoran ternak dapat dilakukan dengan cara menggunakan kotoran ternak sebagai pupuk kandang. Kotoran ternak dimanfaatkan sebagai pupuk kandang karena kandungan unsur haranya seperti nitrogen $(\mathrm{N})$, fosfor $(\mathrm{P})$, dan kalium $(\mathrm{K})$ serta unsur hara mikro diantaranya kalsium, magnesium, belerang, natrium, besi, dan tembaga yang dibutuhkan tanaman dan kesuburan tanah (Hapsari, 2013). Kotoran kambing dapat digunakan sebagai bahan organik pada pembuatan pupuk kandang karena kandungan unsur haranya relatif tinggi dimana kotoran kambing bercampur dengan air seninya (urine) yang juga mengandung unsur hara (Surya, 2013).

Limbah pertanian seperti limbah dari pengolahan kelapa juga dapat dimanfaatkan untuk pupuk organik. Debu sabut merupakan limbah dari penyeratan sabut kelapa. Debu sabut saat ini masih terbatas pemanfaatannya, yaitu sebagai media tanam (Mulyawan et al., 2015). Debu sabut mengandung unsur hara seperti $\mathrm{N}, \mathrm{P}, \mathrm{K}, \mathrm{Ca}, \mathrm{Fe}, \mathrm{Mg}$, $\mathrm{Na}, \mathrm{Mn}, \mathrm{Cu}, \mathrm{Zn}$, dan Al. Unsur hara yang terdapat di debu sabut kelapa sesuai untuk digunakan sebagai pupuk organik (Lay dan Nur, 2014; Mulyawan et al., 2015). Hermawati (2007) dalam Waryanti (2010), melaporkan bahwa $\mathrm{K}_{2} \mathrm{O}$ yang terkandung di dalam debu sabut kelapa sebesar 10,25\%. Debu sabut dapat ditambahkan ke dalam pupuk kandang karena kandungan kalium yang tinggi sehingga meningkatkan kandungan unsur hara $\mathrm{K}$ pada pupuk kandang. Secara umum, kandungan hara dalam kotoran hewan lebih rendah daripada pupuk kimia.

Nilai rasio $\mathrm{C} / \mathrm{N}$ kotoran kambing umumnya diatas 30, oleh karena itu kotoran kambing harus dikomposkan terlebih dahulu sebelum digunakan ke tanaman. Prinsip pengomposan adalah untuk menurunkan rasio $\mathrm{C} / \mathrm{N}$ bahan organik hingga sama dengan $\mathrm{C} / \mathrm{N}$ tanah $(<20)$ (Siboro et al., 2013). Pengomposan adalah proses penguraian bahanbahan organik secara biologis oleh mikrobamikroba yang memanfaatkan bahan organik sebagai sumber energi (Dewi dan Treesnowati, 2012). Proses pengomposan yang terjadi secara alami berlangsung lama dan lambat. Untuk mempercepat proses pengomposan telah dikembangkan teknologi-teknologi pengomposan, antara lain dengan menggunakan aktivator sehingga pengomposan berjalan dengan lebih cepat dan efisien (Arisha et al., 2003). Bioaktivator yang digunakan dalam penelitian ini adalah PROMI dan Orgadec. Mikroba dalam bioaktivator Orgadec yang digunakan dalam pengomposan adalah Trichoroderma Pseudokoningii dan Cytophaga $S p$. Kedua mikroba ini memiliki kemampuan yang tinggi dalam menghasilkan enzim penghancur lignin dan selulosa secara bersamaan (Didik dan Yufnal, 2008). Mikroba yang terdapat dalam PROMI, yaitu Trichoderma Harzianium Dt 38, Pseudokoningii Dt 39, Aspergilus sp. dan fungi. Penggunaan PROMI dan Orgadec pada penelitian ini bertujuan untuk mengetahui pengaruh pemberian bioaktivator yang berbeda terhadap waktu optimal pengomposan dan kualitas pupuk kandang sesuai dengan SNI 19-7030-2004 (Badan Standardisasi Nasional, 2004). 


\section{Materi dan Metode}

Penelitian ini dilakukan di Kebun Percobaan Kima Atas Balai Penelitian Tanaman Palma, selama bulan September-Desember 2015. Bahan penelitian yang digunakan antara lain, kotoran kambing yang berasal dari peternakan Kebun Percobaan Kima Atas, debu sabut kelapa, air, dan bioaktivator PROMI dan Orgadec. Alat yang digunakan, yaitu tempat pengomposan, sekop, plastik terpal, ember, gelas ukur, dan karung.

Pembuatan kompos dilakukan dengan sistem anaerob. Kotoran kambing yang sudah matang dihancurkan terlebih dahulu dengan alat penghancur. Kotoran kambing yang sudah hancur dicampur dengan debu sabut dengan perbandingan 1:1 (total bahan organik $10 \mathrm{~kg}$ ), kemudian tumpukan bahanbahan organik tersebut diberi perlakuan bioaktivator yang berbeda Promi (1 kg dilarutkan dalam 2001 air), dan Orgadec (1 kg dilarutkan dalam 2001 air) secara merata. Tumpukan bahan-bahan organik ditutup dengan plastik terpal. Proses pembalikan dilakukan setiap 3 hari sekali sampai proses pengomposan selesai. Pengujian kualitas pupuk terdiri atas kadar air, nitrogen total, $\mathrm{P}_{2} \mathrm{O}_{5}$, C-organik, $\mathrm{K}$, dan rasio $\mathrm{C} / \mathrm{N}$ yang dilakukan pada hari ke 0,10, 20, 30, 40, dan 50. Nilai kadar air ditentukan dengan metode gravimetri, kadar nitrogen dengan metode kjeldahl, $\mathrm{P}_{2} \mathrm{O}_{5}$ dianalisis dengan metode spektrofotometri, kadar K diukur dengan AAS (Atomic Absorption Spectroscopy), dan kadar C-organik diukur dengan metode titrimetri.

\section{Hasil dan Pembahasan}

Parameter kualitas pupuk kandang yang dianalisis antara lain C-organik, $\mathrm{N}, \mathrm{P}, \mathrm{K}$, rasio $\mathrm{C} / \mathrm{N}$, dan kadar air. Pengaruh lamanya waktu pengomposan terhadap kadar air pupuk kandang ditunjukkan pada Gambar 1.

Kadar air sangat berpengaruh terhadap lamanya pengomposan/penguraian bahan-bahan organik dalam kompos (Widarti et al., 2015). Kadar air berkaitan dengan ketersediaan oksigen untuk aktivitas mikroorganisme aerobik, bila kadar air bahan berada pada kisaran 40-60,5\% maka mikroorganisme pengurai akan bekerja optimal (Sriharti dan Salim, 2002). Kadar air dari bahan kompos berkisar $40 \%$ maka mikroorganisme pengurai dapat bekerja optimal menguraikan bahan-bahan organik dalam kompos. Kadar air mengalami penurunan karena proses penguapan selama pengomposan bahan organik oleh mikroorganisme dan proses pembalikan kompos. Proses pembalikan dilakukan agar kompos

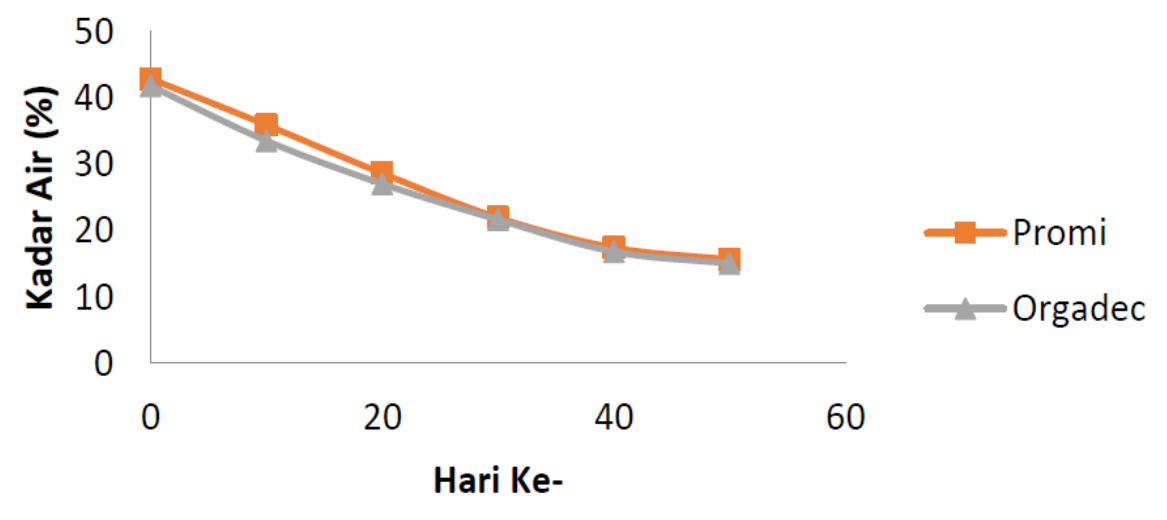

Gambar 1. Pengaruh waktu pengomposan terhadap kadar air 
tidak terlalu lembab/ mengurangi kadar air pada bahan organik. Kelembaban memiliki peranan yang sangat penting dalam proses metabolisme mikroba dan suplai oksigen. Jika kompos terlalu lembab maka akan menyebabkan proses pengomposan berlangsung lebih lama dan jika kelembaban terlalu rendah maka efisiensi degradasi akan menurun karena kurangnya air untuk melarutkan bahan organik yang akan didekomposisi oleh mikroorganisme sebagai sumber energi (Pandebesie dan Rayuanti, 2012).

Karbon (C) dibutuhkan mikroorganisme selama pengomposan. Pengaruh waktu pengomposan terhadap kadar C-organik pupuk kandang ditunjukkan pada Gambar 2.
Semakin lama waktu pengomposan maka kadar karbon dalam pupuk kandang semakin menurun. Hal ini disebabkan oleh mikroba yang menggunakan karbon untuk berkembangbiak (Murtalaningsih, 2001). Mikroba mengambil energi untuk penguraian bahan organik dari kalori yang dihasilkan dalam reaksi biokimia, seperti perubahan zat karbohidrat menjadi gas $\mathrm{CO}_{2}$ dan $\mathrm{H}_{2} \mathrm{O}$ yang terus menerus sehingga kandungan zat karbon dalam pupuk kandang turun semakin rendah (Subali dan Ellianawati, 2010). Kadar C-organik di dalam kompos menunjukkan kemampuannya untuk memperbaiki sifat tanah (Sriharti dan Salim, 2010).

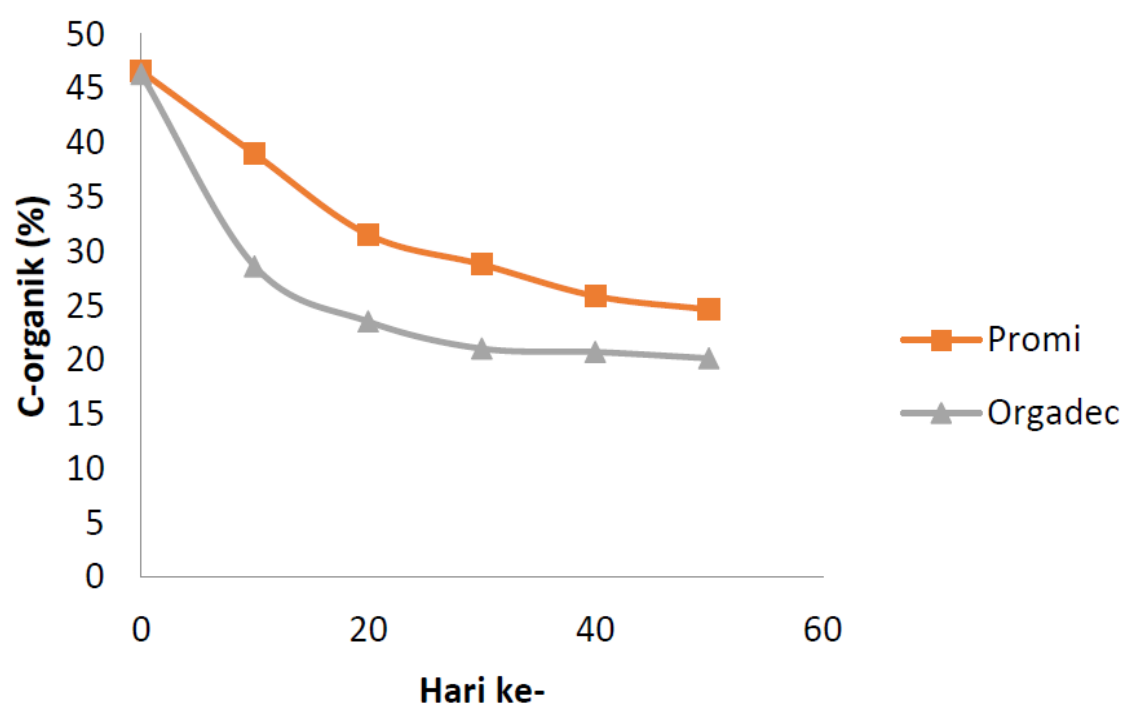

Gambar 2. Pengaruh waktu pengomposan terhadap kadar C-organik

Unsur hara makro yang dibutuhkan oleh tanaman antara lain N, P, dan K. Unsur nitrogen (N) untuk pertumbuhan tunas, batang, dan daun. Fosfor (P) untuk merangsang pertumbuhan akar buah dan biji. Kalium (K) untuk meningkatkan ketahanan tanaman terhadap serangan hama dan penyakit (Santi, 2008). Pengaruh lamanya waktu pengomposan terhadap kadar N, P, dan K pupuk kandang ditunjukkan pada Gambar 3.
Kadar N, P, dan $\mathrm{K}$ awal pengomposan (hari ke-0) pupuk kandang meningkat setelah dilakukan pengomposan. Kadar nitrogen dibutuhkan mikroorganisme untuk pemeliharaan dan pembentukan sel tubuh. Makin banyak kandungan nitrogen, makin cepat bahan organik terurai karena mikroorganisme yang menguraikan bahan kompos memerlukan nitrogen untuk perkembangannya (Sriharti dan Salim, 2010). Nilai nitrogen mengalami 


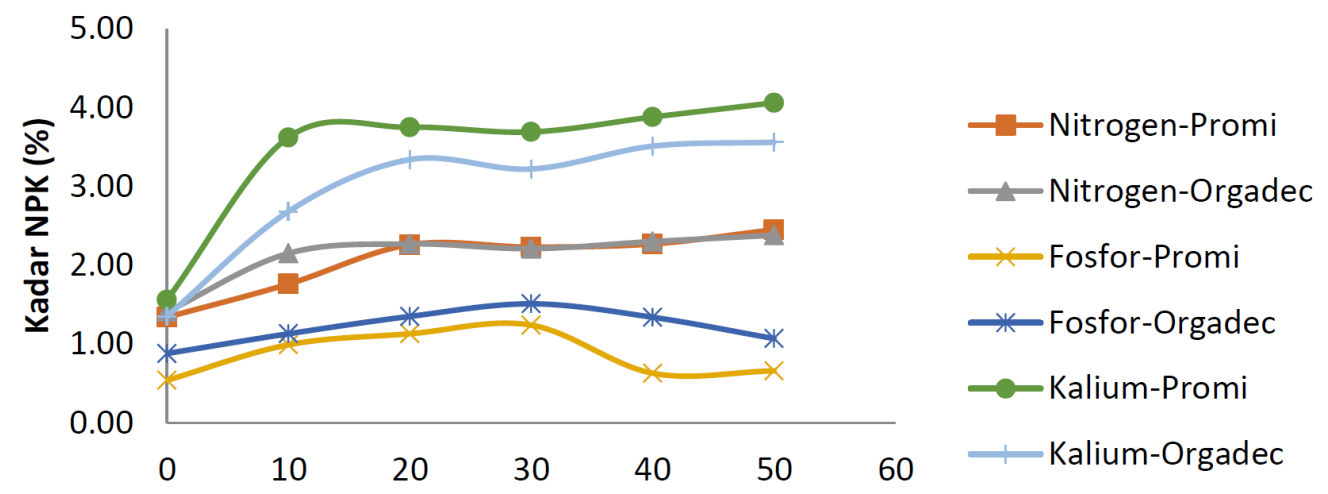

Gambar 3. Pengaruh waktu pengomposan terhadap kadar N, P, dan K

peningkatan dan penurunan selama proses pengomposan. Peningkatan kadar nitrogen pupuk kandang terjadi karena proses dekomposisi yang dilakukan mikroorganisme yang menghasilkan ammonia dan nitrogen. Penurunan kadar nitrogen disebabkan oleh nitrogen yang bereaksi dengan air membentuk $\mathrm{NO}_{3}^{-}$-dan $\mathrm{H}^{+}$. Senyawa $\mathrm{NO}_{3}{ }^{-}$bersifat sangat mobile, sangat larut air, dan tidak dapat dipegang oleh koloid tanah serta akan terjadi kehilangan $\mathrm{N}$ dalam bentuk gas, dimana reaksi $\mathrm{NO}_{3}{ }^{-}$menjadi $\mathrm{N}_{2}$ dan $\mathrm{N}_{2} \mathrm{O}$. Kehilangan $\mathrm{N}$ ini diatasi dengan pembalikan tumpukan pupuk kandang sehingga kadar air berkurang, suplai oksigen yang cukup untuk mikroorganisme mengurai protein menjadi ammonia $\left(\mathrm{NH}_{4}^{+}\right)$, dan proses aerasi yang baik (Cesaria et al., 2010).

Kandungan fosfor juga dipengaruhi oleh tingginya kandungan nitrogen, semakin tinggi nitrogen yang terkandung maka multiplikasi mikroorganisme yang merombak fosfor akan meningkat sehingga terjadi kenaikan kandungan fosfor pada pupuk kandang (Hidayati et al., 2011). Unsur fosfor (P) sebagai bahan organik memiliki peranan yang sangat penting dalam kesuburan tanah, proses fotosintesis, dan fisiologi kimiawi tanaman. Fosfor juga dibutuhkan di dalam pembelahan sel, pengembangan jaringan dan titik tumbuh tanaman (Widarti et al., 2015).
Bakteri pelarut fosfat umumnya juga dapat melarutkan unsur kalium dalam bahan organik. Menurut Hidayati et al., (2011), kalium digunakan oleh mikroorganisme dalam bahan substrat sebagai katalisator, dengan kehadiran bakteri dan aktivitasnya akan sangat berpengaruh terhadap peningkatan kandungan kalium. Kalium dapat diikat dan disimpan dalam sel oleh bakteri dan jamur (Mirwan dan Rosariawari, 2012). Pengikatan unsur kalium berasal dari hasil dekomposisi bahan organik oleh mikroorganisme dalam tumpukan bahan kompos. Bahan kompos yang merupakan bahan organik segar mengandung kalium dalam bentuk organik kompleks yang tidak dapat dimanfaatkan langsung oleh tanaman untuk pertumbuhannya. Aktivitas dekomposisi oleh mikroorganisme mengubah organik komplek tersebut menjadi organik sederhana yang menghasilkan unsur kalium yang dapat diserap tanaman (Widarti et al., 2015)

Nilai rasio $\mathrm{C} / \mathrm{N}$ bahan organik merupakan faktor penting dalam pengomposan. Karbon digunakan sebagai sumber energi dan nitrogen sebagai sumber nutrisi untuk pembentukkan sel-sel tubuh mikroorganisme selama proses pengomposan. Pengaruh waktu pengomposan terhadap rasio $\mathrm{C} / \mathrm{N}$ ditunjukkan pada Gambar 4. 


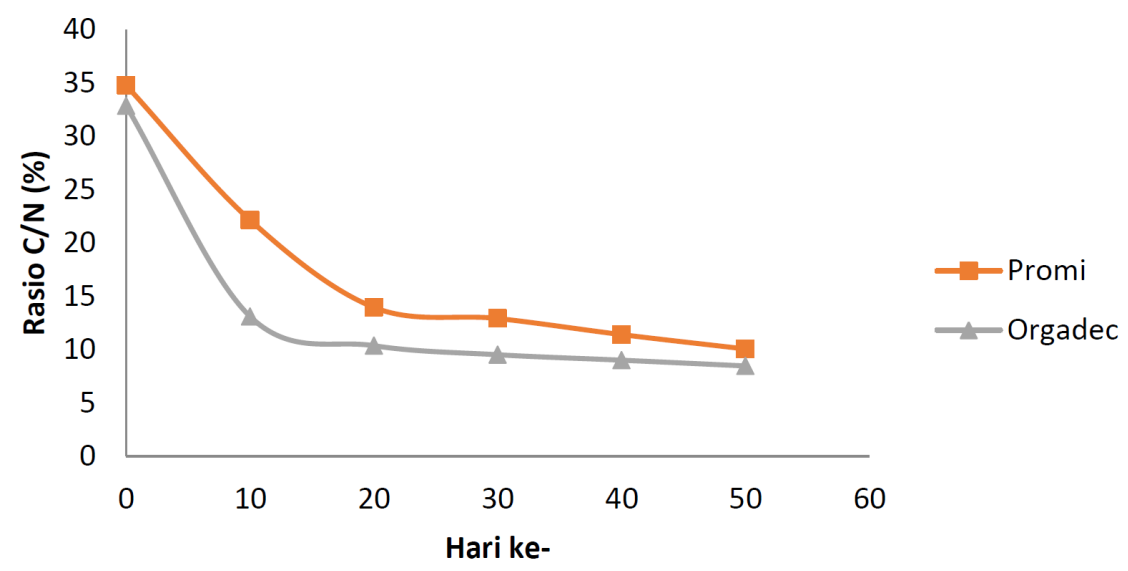

Gambar 4. Pengaruhwaktu pengomposan terhadap rasio $\mathrm{C} / \mathrm{N}$

Pembuatan pupuk kandang dari kotoran kambing dengan cara fermentasi menggunakan PROMI dan Orgadec akan menyebabkan penurunan rasio $\mathrm{C} / \mathrm{N}$. Penurunan nilai rasio $\mathrm{C} / \mathrm{N}$ pada masing-masing bioaktivator disebabkan karena terjadinya penurunan jumlah karbon yang digunakan oleh mikroba sebagau sumber energi untuk menguraikan bahan organik dalam kompos. Selama proses pengomposan terjadi reaksi C menjadi $\mathrm{CO}_{2}$ dan $\mathrm{CH}_{4}$ yang berupa gas dan menguap sehingga menyebabkan penurunan kadar karbon (C). Sedangan, nilai $\mathrm{N}$ total dalam bahan organik mengalami peningkatan karena proses dekomposisi bahan kompos oleh mikroorganisme yang menghasilkan ammonia dan nitrogen, sehingga kadar $\mathrm{N}$ total kompos meningkat. Dengan menurunnya kandungan C-organik dan meningkatnya kandungan $\mathrm{N}$ total maka rasio $\mathrm{C} / \mathrm{N}$ mengalami penurunan. Bahan organik sudah menjadi kompos/pupuk dan dapat digunakan untuk tanaman apabila rasio $\mathrm{C} / \mathrm{N}<20$ (Yuniwati et al., 2012).

Pupuk yang telah matang memiliki ciri-ciri, yaitu berwarna coklat tua hingga hitam, remah, memiliki suhu ruang, dan tidak berbau. Hasil analisis kualitas pupuk kandang dibandingkan dengan SNI 19-7030-2004 untuk mengetahui apakah pupuk kandang hasil pengomposan memenuhi kriteria Standar Nasional Indonesia (SNI) dan layak digunakan pada tanaman. Hasil analisis pupuk kandang dengan bioaktivator PROMI ditunjukkan pada Tabel 1 dan pupuk kandang dengan bioaktivator Orgadec ditunjukkan pada Tabel 2.

Tabel 1. Hasil analisis pupuk kandang dengan bioaktivator PROMI dan SNI 19-7030-2004

\begin{tabular}{|c|c|c|c|c|c|c|c|c|c|c|}
\hline \multirow{2}{*}{ Parameter } & \multicolumn{3}{|c|}{$\begin{array}{c}\text { Standar SNI 19-7030- } \\
2004\end{array}$} & \multirow{2}{*}{$\begin{array}{c}\text { Kotoran } \\
\text { Kambing }\end{array}$} & \multicolumn{6}{|c|}{ Hari ke- } \\
\hline & Satuan & Min & Maks & & 0 & 10 & 20 & 30 & 40 & 50 \\
\hline C-Organik & $\%$ & 9,80 & 32 & 47,34 & $46,58^{*}$ & $38,96^{*}$ & 31,53 & 28,78 & 25,87 & 24,63 \\
\hline Nitrogen & $\%$ & 0,40 & & 1,45 & 1,34 & 1,76 & 2,26 & 2,23 & 2,27 & 2,45 \\
\hline Fosfor & $\%$ & 0,10 & & 0,35 & 0,54 & 0,99 & 1,13 & 1,24 & 0,63 & 0,66 \\
\hline Kalium & $\%$ & 0,20 & & 1,03 & 1,56 & 3,62 & 3,75 & 3,69 & 3,88 & 4,06 \\
\hline Rasio C/N & & 10 & 20 & 32,65 & $34,76^{*}$ & $22,14^{*}$ & 13,95 & 12,91 & 11,40 & 10,05 \\
\hline Kadar Air & $\%$ & & 50 & 35,91 & 42,88 & 35,91 & 28,63 & 21,95 & 17,44 & 15,66 \\
\hline
\end{tabular}


Tabel 2 Hasil analisis pupuk kandang dengan bioaktivator Orgadec dan SNI 19-7030-200

\begin{tabular}{|c|c|c|c|c|c|c|c|c|c|c|}
\hline \multirow{2}{*}{ Parameter } & \multicolumn{3}{|c|}{$\begin{array}{c}\text { Standar SNI 19-7030- } \\
2004\end{array}$} & \multirow{2}{*}{$\begin{array}{l}\text { Kotoran } \\
\text { Kambing }\end{array}$} & \multicolumn{6}{|c|}{ Hari ke- } \\
\hline & Satuan & Min & Maks & & 0 & 10 & 20 & 30 & 40 & 50 \\
\hline C-Organik & $\%$ & 9,80 & 32 & 47,34 & $46,32^{*}$ & 28,61 & 23,52 & 21,03 & 20,72 & 20,14 \\
\hline Nitrogen & $\%$ & 0,40 & & 1,45 & 1,41 & 2,15 & 2,27 & 2,21 & 2,30 & 2,38 \\
\hline Fosfor & $\%$ & 0,10 & & 0,35 & 0,88 & 1,13 & 1,35 & 1,51 & 1,34 & 1,07 \\
\hline Kalium & $\%$ & 0,20 & & 1,03 & 1,35 & 2,68 & 3,34 & 3,22 & 3,51 & 3,56 \\
\hline Rasio $\mathrm{C} / \mathrm{N}$ & & 10 & 20 & 32,65 & $32,85^{*}$ & 13,10 & 10,36 & $9,51 *$ & $9,00^{*}$ & $8,46^{*}$ \\
\hline Kadar Air & $\%$ & & 50 & 35,91 & 41,79 & 33,53 & 27,04 & 21,66 & 16,83 & 15,05 \\
\hline
\end{tabular}

Keterangan: *tidak memenuhi SNI 19-7030-2004

Nilai rasio $\mathrm{C} / \mathrm{N}$ kotoran kambing $>30$, yaitu 47,34 yang berarti kotoran kambing harus dikomposkan terlebih dahulu sebelum digunakan sebagai pupuk pada tanaman. Kondisi awal (hari ke0) pengomposan bahan organik memiliki nilai rasio $\mathrm{C} / \mathrm{N}$ awal yang memenuhi kriteria nilai $\mathrm{C} / \mathrm{N}$ awal untuk bahan kompos, yaitu berkisar antara 30-50 (Salim dan Sriharti, 2008). Kandungan C-organik yang tinggi menunjukkan bahwa bahan organik tersebut cukup untuk mikroorganisme mendapatkan energi selama proses dekomposisi. Hasil analisis pupuk kandang dengan bioaktivator PROMI yang memenuhi parameter-parameter SNI 19-7030-2004 adalah pengomposan selama $20,30,40$, dan 50 hari, sedangkan pupuk kandang dengan bioaktivator Orgadec adalah 10 dan 20 hari pengomposan. Orgadec lebih efektif dan memerlukan waktu pengomposan yang lebih cepat (<20 hari) daripada bioaktivator PROMI (>20 hari) untuk mendekomposisi kotoran kambing dan debu sabut kelapa. Debu sabut kelapa mengandung komponen yang sulit terdekomposisi seperti lignin, resin, dan lilin (Susanto, 2002; Ruskandi, 2006). Orgadec mengandung mikroba (Trichoroderma Pseudokoningii dan Cytophaga Sp) yang memiliki kemampuan tinggi dalam menghasilkan enzim penghancur lignin dan selulosa secara bersamaan. Dengan hancurnya lignin dan selulosa maka kadar karbon akan turun dan kadar nitrogen akan meningkat shingga rasio $\mathrm{C} / \mathrm{N}$ menjadi kecil (Mey, 2013). Bioaktivator Orgadec lebih efektif mendekomposisi bahan organik yang mengandung lignin dan selulosa seperti debu sabut kelapa.

Waktu pengomposan pupuk kandang dengan bioaktivator Orgadec yang tidak memenuhi SNI 197030-2004 (rasio C/N 10-20), yaitu pengomposan selama $0,30,40$, dan 50 hari. Semakin lama proses pengomposan dilakukan maka rasio $\mathrm{C} / \mathrm{N}$ semakin kecil (Surtinah, 2013). Hal ini disebabkan oleh kadar C dalam bahan kompos sudah banyak berkurang karena digunakan oleh mikroorganisme sebagai sumber makanan/energi, sedangkan kandungan nitrogen mengalami peningkatan karena proses dekomposisi bahan kompos oleh mikroorganisme yang menghasilkan ammonia dan nitrogen sehingga rasio $\mathrm{C} / \mathrm{N}$ menurun. Waktu pengomposan pupuk kandang dengan bioaktivator PROMI yang tidak memenuhi SNI 19-7030-2004 (rasio C/N 1020), pengomposan pada 0 dan 10 hari. Hal ini disebabkan oleh belum cukup waktu mikroba untuk mendekomposisi bahan organik dalam kompos. 


\section{Kesimpulan}

Pengomposan pupuk kandang dari kotoran kambing dan debu sabut kelapa dengan bioaktivator Orgadec lebih efektif dibandingkan dengan bioaktivator PROMI, yaitu $<20$ hari. Bioaktivator Orgadec memerlukan waktu pengomposan yang lebih cepat daripada bioaktivator PROMI dalam mendekomposisi bahan organik dalam kotoran kambing dan debu sabut. Kualitas pupuk kandang dengan bioaktivator Orgadec memenuhi SNI 197030-2004 (rasio C/N, kadar N, P, K, air, dan C-organik), yaitu pada pengomposan selama 10 dan 20 hari, sedangkan pupuk kandang dengan bioaktivator PROMI pada pengomposan selama 20, 30, 40 dan 50 hari

\section{Daftar Pustaka}

Arisha, H.M.E., Gad, A.A., dan Younes, S.E. 2003. Response of some pepper cultivar to organic and mineral nitrogen fertilizer under sandy soil conditions. Zagazig J. Agric. Res. 30: 1875-99.

Badan Standardisasi Nasional. 2004. Spesifikasi Kompos dari Sampah Organik Domestik. SNI 19-7030-2004. Jakarta.

Cesaria, R.Y., Wirosoedarmo, R., Suharto, B. 2010. Pengaruh penggunaan starter terhadap kualitas fermentasi limbah cair tapioka sebagai alternatif pupuk cair.Jurnal Sumberdaya Alam dan Lingkungan 12(2):8-14.

Dewi, Y.S., Treesnowati. 2012. Pengolahan sampah skala rumah tangga menggunakan metode composting. Jurnal Ilmiah Fakultas Teknik LIMIT'S. 8(2): 35-48.

Didik, H.G., dan Yufnal. A. 2008. OrgaDec. Balai Penelitian Biotek Perkebunan Indonesia.

Hapsari, A.Y. 2013. Kualitas dan kuantitas kandungan pupuk organik limbah serasah dengan inokulum kotoran sapi secara semianaerob. skripsi. Fakultas
Keguruan dan Ilmu Pendidikan. Universitas Muhammadiyah Surakarta.

Hermawati, T. 2007. Tanaman semangka (Citrullus vulgaris Schars) terhadap pemberian berbagai dosis abu sabut kelapa. Jurnal Agronomi 11(2): 77-80.

Hidayati, Y.A., Kurnani, A., Marlina, E.T., Harlia, E. 2011. Kualitas pupuk cair hasil pengolahan fases sapi potong menggunakan Saccharomyces cereviceae. Jurnal Ilmu Ternak 11(2): 104-107.

Lay, A., Nur., M. 2014. Aplikasi model renewable cycle sistem (RCS) pada usaha tani kelapa. Prosiding Konferensi Nasional Kelapa VIII, Jambi, 21-22 Mei 2014. p. 113-120.

Mey, D. 2013. Uji efektivitas mikroorganisme terhadap laju dekomposisi limbah jambu mete sebagai pupuk organik di Sulawesi Tenggara. AGRIPLUS 23(2): 85-91.

Mirwan, M., Rosariawari,F. 2012. Optimasi pematangan kompos dengan penambahan campuran lindi dan bioaktivator stardec. Jurnal Ilmiah Teknik Lingkungan 4(2): 150-154.

Mulyawan, M., Setyowati, E., Widjaja, A. 2015. Surfaktan sodium ligno sulfonat (SLS) dari debu sabut kelapa.Jurnal Teknik ITS 4(1): 1-3.

Murtalaningsih. 2001. Studi pengaruh penambahan bakteri dan cacing tanah terhadap laju reduksi dan kualitas kompos. Laporan Tugas Akhir. FTSP-ITS. Surabaya.

Pandebesie, E.S., Rayuanti, D. 2013. Pengaruh penambahan sekam pada proses pengomposan sampah domestik. Jurnal Lingkungan Tropis 6(1): 31-40.

Ruskandi. 2006. Teknik pembuatan kompos limbah kebun pertanaman kelapa polikultur. Buletin Teknik Pertanian 11(1): 33-36.

Salim, T., Sriharti. 2008. Pemanfaatan limbah industri pengolahan dodol nanas sebagai kompos dan aplikasinya pada tanaman tomat. Prosiding Seminar Nasional Teknoin 2008 Bidang Teknik Kimia dan Tekstil, Yogyakarta, 22 November 2008. p. 72-77. 
Santi, S.S. 2008. Kajian pemanfaatan limbah nilam untuk pupuk cair organik dengan proses fermentasi. Jurnal Teknik Kimia 2(2): 170-175.

Siboro, E.S., Surya, E., Herlina, N. 2013. Pembuatan pupuk cair dan biogas dari campuran limbah sayuran.Jurnal Teknik Kimia USU 2(3): 40-43.

Sriharti., Salim, T. 2010. Pemanfaatan sampah tanam (rumput-rumputan) untuk pembuatan kompos.Prosiding Seminar Nasional Teknik Kimia "Kejuangan" Pengembangan Teknologi Kimia untuk Pengolahan Sumber Daya Alam Indonesia, Yogyakarta, 26 Januari 2010. p. 1-8.

Subali, B., Ellianawati. 2010. Pengaruh waktu pengomposan terhadap rasio unsur $\mathrm{C} / \mathrm{N}$ dan jumlah kadar air dalam kompos. Prosiding Pertemuan Ilmiah XXIV HFI Jateng \& DIY, Semarang, 10 April 2010. p. 49-53.

Surtinah. 2013. Pengujian kandungan unsur hara dalam kompos yang berasal dari serasah tanaman jagung manis (Zea mays saccharata). Jurnal Ilmiah Pertanian 11(1): 16-25.
Surya, R.E., Suryono. 2013. Pengaruh pengomposan terhadap rasio $\mathrm{C} / \mathrm{N}$ kotoran ayam dan kadar hara NPK tersedia serta kapasitas tukar kation tanah. UNESA Journal of Chemistry 2(1): 137-144.

Sutanto, R. 2002. Pupuk Organik: potensi biomassa dan proses pengomposan. Yogyakarta: Kanisius. hlm. 35-56.

Waryanti, A., Sudarno., Sutrisno, E. 2010. Studi pengaruh penambahan sabut kelapa pada pembuatan pupuk cair dari limbah cucian ikan terhadap kualitas unsur hara makro (CNPK). Jurnal Agronomi 11(2): 1-7.

Widarti, B.N., Wardhini, W.K., Sarwono, E. 2015. Pengaruh rasio $\mathrm{C} / \mathrm{N}$ bahan baku pada pembuatan kompos dari kubis dan kulit pisang. Jurnal Integrasi Proses 5(2): 75-80.

Yuniwati, M., Iskarima, F., Padulemba, A. 2012. Optimasi kondisi proses pembuatan kompos dari sampah organik dengan cara fermentasi menggunakan EM4. Jurnal Teknologi 5(2):172181. 